\title{
The Impact of Dichlorvos -Pesticide on African Catfish Clarias Gariepinus
}

\author{
Nwamba Helen 0*, Achikanu Cosmas E and Chukwu Ginika P \\ Department of Applied Biology, Enugu State University of Science and Technology, Nigeria
}

Submission: November 13, 2018; Published: December 05, 2018

Corresponding author: Nwamba Helen O, Department of Applied Biology, Enugu State University of Science and Technology, Enugu State, Nigeria

\begin{abstract}
The toxicity of dichlorvos (18 $-20 \mathrm{mg} / \mathrm{L}$ ) on Clarias gariepinus juveniles (mean weight $41.6 \pm 1.2(\mathrm{~g})$ and mean length $18.5 \pm 2.5$ (cm) was

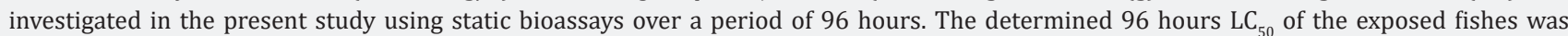
$17.21 \mathrm{mg} / \mathrm{L}$ with lower and upper confidence limits of $15.78-18.19 \mathrm{mg} / \mathrm{L}$ respectively. When the fishes were exposed there was strong evidence of stress responses characterised by hyperactive swimming with subsequent erratic with jerky movements before death which increases with time and concentration of exposure. The quality of water investigated in this study showed no change in dissolved oxygen, pH and temperature. The hepatosomatic indices (HSI) and condition factors (K) which are stress indices due to environmental pollutants decreased within 15 days of exposure and increase in concentration of dichlorvos indicating that it has detrimental effect on the liver of exposed fish with time.
\end{abstract}

\section{Introduction}

The useful state of water for humans and animals that is appropriate has become a rife concern [1]. There is a rapid decline in the quality of water from natural water resources arising from the demand of industrialisation which employ application of synthetic fertilisers and use of various insecticides and pesticides. Chemicals of agricultural or industrial origins have been reported to be source of contaminations to aquatic ecosystems by runoff and ground leaching through the area [2]. Dichlorvos (2,2- dichlorvinyl dimethyl phosphate) an agricultural insecticide is used to control household pests in public health and protecting crops and stored products. It is reported to be effective against mushroom flies, aphids, spiders, mites, caterpillars, whiteflies in greenhouse, outdoor fruits and vegetable crops [3]. It has contact and stomach insecticidal effect on food and non-food crop pests [4] and anticholinesterase action associated with the nervous systems of insects $[3,5]$ stated that the volatility of dichlorvos will favour the vaporisation of a significant proportion of applied substance into the external atmosphere which is expected to dissipate rapidly through dilution, degradation and precipitation, reducing the atmospheric (concentrations well below levels. However, aquatic lives run a risk of toxicity if rain falls within 4 hours of application. Increased use of pesticides results in the excess inflow of toxic chemicals, mainly into the aquatic ecosystem [6,7]. This work aims at investigating the effects of dichlorvos on the wellbeing of aquatic organisms particularly on African catfish C. gariepinus. It belongs to the Claridae family and it is geographically located in Africa, the middle east, Brazil and Indonesia. They make fresh water, lakes, rivers and swamps and human made oxidative ponds and urban sewage system their habitats. The adult catfish can be $1-1.5 \mathrm{~m}$ in length and weigh up to $60 \mathrm{~kg}$ with flat body head, broad terminal mouth with four pairs of barbells and large accessory breathing organs made up of modified gill arches [8].

\section{Materials and Methods}

\section{Source of experimental fish}

One hundred juveniles of $C$. gariepinus were obtained from Rojenny tourist game village, Idemili LGA. Anambra state, Nigeria in 300 litre capacity plastic containers and transported to Heildin fisheries laboratory unit in Enugu state, Nigeria. The mean body weight and the length of the species were $41.6 \pm 1.2(\mathrm{~g})$ and $18.5 \pm 2.5$ (cm) respectively.

\section{Acclimatisation}

The fish were acclimatised to laboratory conditions for 14 days and fed with top fish feed with crude protein of $38 \%$ on daily basis. The container was cleaned, and the water changed every morning. Less than $2 \%$ mortality was observed during the acclimatisation.

\section{Range finding test}

The preliminary tests to determine the range of concentrations used in this experiment were performed by exposing 10 juvenile catfish to 25 litres of dechlorinated tap water containing 18,20 and $22 \mu \mathrm{l}$ of dichlorvos respectively for 96 hours until suitable concentration that produced $100 \%$ mortality was obtained. The fish were not fed for 24 hours before and during the exposure time. 


\section{Experimental procedures}

10 juvenile catfish were exposed to different concentrations of 18,20 and $22 \mu$ l dichlorvos in 10 litres of dechlorinated water from volume to volume $(\mathrm{v} / \mathrm{v})$ stock solution $(10 \mathrm{ml}$ of concentrated dichlorvos in 1 litre of dechlorinated water) in triplicates. The mortality rate, behavioural characteristics of the catfish and the physicochemical properties of water such as $\mathrm{pH}$, temperature, and dissolve oxygen were analysed every 24 hours for 96 hour period [9]. The 96 hours lethal concentration (LC50) of dichlorvos was determined following the probity analysis method [10]. Dead fishes were removed from the experiment pond every morning to avoid contamination at every 24 hours interval for 96 hours. Based on the 96 hours LC50 value, the hepatosomatic indices (HSI) and condition factor (CF) of the Catfishes exposed to two sub-lethal concentrations of dichlorvos (21 and $43 \mathrm{mg} / \mathrm{L}$ ) for 15 days were then determined according to White and Flecher
(1985). A set of 10 fish were also maintained in dechlorinated tap water $(0.00 \mathrm{mg} / \mathrm{l})$ as the control. The experiment was set in triplicates.

\section{Statistics}

Using the SPSS statistical package (version 17), the standard error mean (SEM) and Duncan's multiple range test were used to determine the significance at $10 \%$ probability test. The significance between data were analysed with the one-way analysis of variance (ANOVA).

\section{Result}

At the highest concentration of $22 \mathrm{mg} / \mathrm{L}$ dichlorvos, 87 percent mortality of juvenile catfish was recorded within the 24 to 96 hours exposure. The least percentage mortality was observed in in the lowest concentration of $18 \mathrm{mg} / \mathrm{L}$. No death was recorded in the control during the period of exposure (Table1).

Table 1: Percent Mortality of juvenile African Catfish C. gariepinus exposed to different concentrations of dichlorvos for $24,48,72$ and 96 hours.

\begin{tabular}{|c|c|c|c|c|c|c|c|c|}
\hline \multirow{2}{*}{ Concentration $\mathrm{mg} / \mathrm{L}$} & \multirow{2}{*}{ Number of fishes exposed to pesticide } & \multicolumn{4}{|c|}{ Mortality with time (hours). } & \multirow{2}{*}{ Total rate } & \multirow{2}{*}{$\%$ of survival } & \multirow{2}{*}{$\%$ of mortality } \\
\hline & & 24 & 48 & 72 & 96 & & & \\
\hline Control & 30 & $0^{\mathrm{a} 1}$ & 0a1 & $0^{\mathrm{a} 1}$ & $0^{\mathrm{a} 1 \mathrm{1}}$ & $0^{a 1}$ & $100^{\mathrm{a} 1}$ & $0^{\mathrm{a} 1}$ \\
\hline 18 & 30 & $0^{\mathrm{a} 1}$ & 1a1 & $3^{\mathrm{a} 1}$ & $4^{\mathrm{a} 1}$ & $8^{\mathrm{b} 2}$ & $73.3^{\mathrm{a} 1}$ & $26.7^{\mathrm{a} 1}$ \\
\hline 20 & 30 & $0^{\mathrm{a} 1}$ & $6 \mathrm{~b} 2$ & $9^{\mathrm{b} 2}$ & $5^{\mathrm{b} 2}$ & $20^{\mathrm{b} 2}$ & $33.3^{\mathrm{b} 2}$ & $66.7^{\mathrm{b} 2}$ \\
\hline 22 & 30 & $2^{\mathrm{a} 1}$ & $10^{\mathrm{b} 2}$ & $6 \mathrm{~b} 2$ & $8^{\mathrm{b} 2}$ & $26^{\mathrm{b} 2}$ & $13.3^{\mathrm{b} 2}$ & $86.7^{\mathrm{b} 2}$ \\
\hline
\end{tabular}

Table 2: Behavioural characteristics of juvenile African Catfish C. gariepinus exposed to different concentrations of dichlorvos for $24,48,72$ and 96 hours.

\begin{tabular}{|c|c|c|c|c|c|}
\hline Concentration mg/L & Air gulping & Hyper Activity & Erratic swimming & Equilibrium status & Skin discolouration \\
\hline \multicolumn{6}{|c|}{$24 \mathrm{hrs}$} \\
\hline Control & - & - & - & - & - \\
\hline 18 & + & + & ++ & ++ & - \\
\hline 20 & + & + & ++ & ++ & - \\
\hline 22 & + & + & ++ & ++ & - \\
\hline \multicolumn{6}{|c|}{ 48hrs } \\
\hline Control & - & - & - & - & - \\
\hline 18 & - & - & - & - & - \\
\hline 20 & + & + & ++ & ++ & + \\
\hline 22 & + & + & ++ & ++ & + \\
\hline \multicolumn{6}{|c|}{$72 \mathrm{hrs}$} \\
\hline Control & - & - & - & - & - \\
\hline 18 & + & ++ & ++ & + & + \\
\hline 20 & + & +++ & ++ & + & ++ \\
\hline 22 & ++ & +++ & ++ & + & +++ \\
\hline \multicolumn{6}{|c|}{ 96hrs } \\
\hline Control & - & - & - & - & - \\
\hline 18 & + & ++ & +++ & ++ & ++ \\
\hline 20 & ++ & ++ & +++ & ++ & ++ \\
\hline 22 & +++ & ++ & +++ & ++ & ++ \\
\hline
\end{tabular}

The following keys represent; - None, + Mild, ++ Moderate, +++ Strong

The percent mortality increased with increasing concentration. 20 and 22mg/L dichlorvos for 24,48,72 and 96 hours respectively

The behavioural responses of the juvenile catfish exposed to 18, showed faster swimming, opercula activity, surfacing and gulping 


\section{Oceanography \& Fisheries Open access Journal}

of air in almost all concentrations at exposure time compared to the control. However, at higher concentrations of 20 and $22 \mathrm{mg} / \mathrm{L}$, within 40 minutes of exposure the fish appeared to be hyperactive and swimming became erratic with jerky movements while at $18 \mathrm{mg} / \mathrm{L}$, the fish showed normal behaviour for the first 48hours then stopped swimming and remained static in response to the changes in the surrounding environment. There was mean $\mathrm{pH}$ 7.1, temperature $27{ }^{\circ} \mathrm{C}$ and dissolve oxygen 5.1 for water quality in various treatments with dichlorvos. The lethal concentration of dichlorvos that will kill 10-90\% ( $\mathrm{LC}_{10-90}$ ) of the experimental Table 3: Mean water parameters of juvenile African Catfish C. gariepinus exposed to different concentrations of dichlorvos.

\begin{tabular}{|c|c|c|c|}
\hline Concentration mg/L & pH & Temperature $\left({ }^{\circ} \mathrm{C}\right)$ & Dissolved oxygen $\mathrm{Mg} / \mathrm{L}$ \\
\hline Control & $7.1 \pm 0.0^{\mathrm{a} 1}$ & $28 \pm 0.0^{\mathrm{a} 1}$ & $5.1 \pm 0.0^{\mathrm{a} 1}$ \\
\hline 18 & $7.1 \pm 0.0^{\mathrm{a} 1}$ & $27 \pm 0.0^{\mathrm{a} 1}$ & $5.1 \pm 0.0^{\mathrm{a} 1}$ \\
\hline 20 & $7.1 \pm 0.0^{\mathrm{a} 1}$ & $27 \pm 0.0^{\mathrm{a} 1}$ & $5.1 \pm 0.0^{\mathrm{a} 1}$ \\
\hline 22 & $7.1 \pm 0.0^{\mathrm{a} 1}$ & $27 \pm 0.0^{\mathrm{a} 1}$ & $5.0 \pm 0.0^{\mathrm{a} 1}$ \\
\hline Standard & $6.7-8.5$ & $26-28$ & $5-10$ \\
\hline
\end{tabular}

Table 4: Lethal Concentrations (LC) of Dichlorvos on juvenile African Catfish C. gariepinus exposed for 24, 48, 72 and 96 hours.

\begin{tabular}{|c|c|c|c|c|}
\hline \multirow{2}{*}{ Lethal concentration } & \multicolumn{4}{|c|}{ Hours } \\
\cline { 2 - 5 } & $\mathbf{2 4}$ & $\mathbf{4 8}$ & $\mathbf{7 2}$ & $\mathbf{9 6}$ \\
\hline $\mathbf{L C}_{\mathbf{1 0}}$ & $15.73(14.03-16.89)^{\mathrm{a} 1}$ & $16.12(14.05-17.50)^{\mathrm{a} 1}$ & $15.73(14.03-16.89)^{\mathrm{a} 1}$ & $15.73(14.03-16.89)^{\mathrm{a} 1}$ \\
\hline $\mathbf{L C}_{\mathbf{2 0}}$ & $16.31(14.71-17.40)^{\mathrm{a} 1}$ & $16.84(14.90-18.12)^{\mathrm{a} 1}$ & $16.31(14.71-17.40)^{\mathrm{a} 1}$ & $16.31(14.71-17.40)^{\mathrm{a} 1}$ \\
\hline $\mathbf{L C}_{\mathbf{3 0}}$ & $16.68(15.5-17.73)^{\mathrm{a} 1}$ & $17.31(15.47-18.5)^{\mathrm{b} 2}$ & $16.68(15.15-17.73)^{\mathrm{a} 1}$ & $16.68(15.15-17.73)^{\mathrm{a} 1}$ \\
\hline $\mathbf{L C}_{\mathbf{4 0}}$ & $16.97(15.50-17.98)^{\mathrm{a} 1}$ & $17.68(15.90-18.54)^{\mathrm{b} 2}$ & $16.97(15.50-17.98)^{\mathrm{a} 1}$ & $16.97(15.50-17.98)^{\mathrm{a} 1}$ \\
\hline $\mathbf{L C}_{\mathbf{5 0}}$ & $17.21(15.78-18.19)^{\mathrm{b} 2}$ & $17.98(16.27-19.35)^{\mathrm{b} 2}$ & $17.21(15.78-18.19)^{\mathrm{b} 2}$ & $17.21(15.78-18.19)^{\mathrm{b} 2}$ \\
\hline $\mathbf{L C}_{\mathbf{6 0}}$ & $17.24(16.03-18.37)^{\mathrm{b} 2}$ & $18.24(16.59-19.12)^{\mathrm{b} 2}$ & $17.41(16.03-18.37)^{\mathrm{b} 2}$ & $17.42(16.03-18.19)^{\mathrm{b} 2}$ \\
\hline $\mathbf{L C}_{\mathbf{7 0}}$ & $17.60(16.25-18.53)^{\mathrm{b} 2}$ & $18.48(16.87-19.35)^{\mathrm{b} 2}$ & $17.60(16.25-18.53)^{\mathrm{b} 2}$ & $17.60(16.25-18.53)^{\mathrm{b} 2}$ \\
\hline $\mathbf{L C}_{\mathbf{8 0}}$ & $17.77(16.44-18.68)^{\mathrm{b} 2}$ & $18.69(17.12-19.74)^{\mathrm{b} 2}$ & $17.77(16.44-18.68)^{\mathrm{b} 2}$ & $17.77(16.44-18.68)^{\mathrm{b} 2}$ \\
\hline $\mathbf{L C}_{\mathbf{9} \mathbf{y y y y}}$ & $17.92(16.62-18.81)^{\mathrm{b} 2}$ & $18.88(17.36-19.91)^{\mathrm{b} 2}$ & $17.92(16.62-18.81)^{\mathrm{b} 2}$ & $17.92(16.62-18.61)^{\mathrm{b} 2}$ \\
\hline
\end{tabular}

Values outside the brackets are Lethal Concentrations (LC). First value within the bracket is the lower confidence and the second value is the upper confidence respectively. Value with different numeric superscripts differ significantly $(P<0.05)$ between different concentrations within the same exposure duration.

Table 5: Hepatosomatic indices (HSI) of juvenile African Catfish C.gariepinus exposed to sublethal concentrations of Dichlorvos for 1 , 5,10 and 15 days.

\begin{tabular}{|c|c|c|c|}
\hline \multirow{2}{*}{ Exposure days } & \multirow{2}{*}{ Control } & \multicolumn{2}{|c|}{ Concentration $\mathbf{~ m} / \mathbf{L}$} \\
\cline { 3 - 4 } & & $\mathbf{2 1}$ & $\mathbf{4 3}$ \\
\hline 1 & $1.03 \pm 0.42^{\mathrm{b} 2}$ & $1.69 \pm 0.59^{\mathrm{b} 2}$ & $1.22 \pm 0.12^{\mathrm{b} 2}$ \\
\hline 5 & $0.77 \pm 0.36^{\mathrm{b} 2}$ & $0.76 \pm 0.35^{\mathrm{b} 2}$ & $0.88 \pm 0.27^{\mathrm{b} 2}$ \\
\hline 10 & $0.92 \pm 1.62^{\mathrm{b} 2}$ & $0.71 \pm 0.88^{\mathrm{b} 2}$ & $0.50 \pm 0.66^{\mathrm{b} 2}$ \\
\hline 15 & $0.75 \pm 0.10^{\mathrm{b} 2}$ & $0.88 \pm 0.10^{\mathrm{b} 2}$ & $0.60 \pm 0.40^{\mathrm{b} 2}$ \\
\hline
\end{tabular}

Values with different alphabetic (lower case) superscripts differ significantly $(P<0.05)$ between exposure periods within the same concentration. The values with different numeric superscripts differ significantly $(P<0.05)$ between different concentrations within the same exposure duration.

Table 6: Condition factor (CF) of juvenile African Catfish C. gariepinus exposed to sublethal concentrations of Dichlorvos for 1, 5, 10 and 15 days.

\begin{tabular}{|c|c|c|c|}
\hline \multirow{2}{*}{ Exposure (days) } & \multirow{2}{*}{ Control } & \multicolumn{2}{|c|}{ Concentration (mg/L) } \\
\cline { 3 - 4 } & & $\mathbf{2 1}$ & $\mathbf{4 3}$ \\
\hline 1 & $1.74 \pm 0.57^{\mathrm{b} 2}$ & $2.47 \pm 0.57^{\mathrm{b} 2}$ & $2.81 \pm 0.48^{\mathrm{b} 2}$ \\
\hline
\end{tabular}

\begin{tabular}{|c|c|c|c|}
\hline 5 & $1.71 \pm 0.00^{\mathrm{a} 1}$ & $3.59 \pm 3.76^{\mathrm{b} 2}$ & $1.64 \pm 0.46^{\mathrm{b} 2}$ \\
\hline 10 & $5.53 \pm 0.53^{\mathrm{b} 2}$ & $2.36 \pm 2.56^{\mathrm{b} 2}$ & $2.29 \pm 1.34^{\mathrm{b} 2}$ \\
\hline 15 & $6.51 \pm 0.99^{\mathrm{b} 2}$ & $1.23 \pm 0.01^{\mathrm{a} 1}$ & $1.17 \pm 0.17^{\mathrm{b} 2}$ \\
\hline
\end{tabular}

Values with different alphabetic (lowercase) superscripts differ significantly $(P<0.05)$ between exposure periods within the same concentration. Value with different numeric superscripts differ significantly $(P<0.05)$ between different concentrations within the same exposure duration

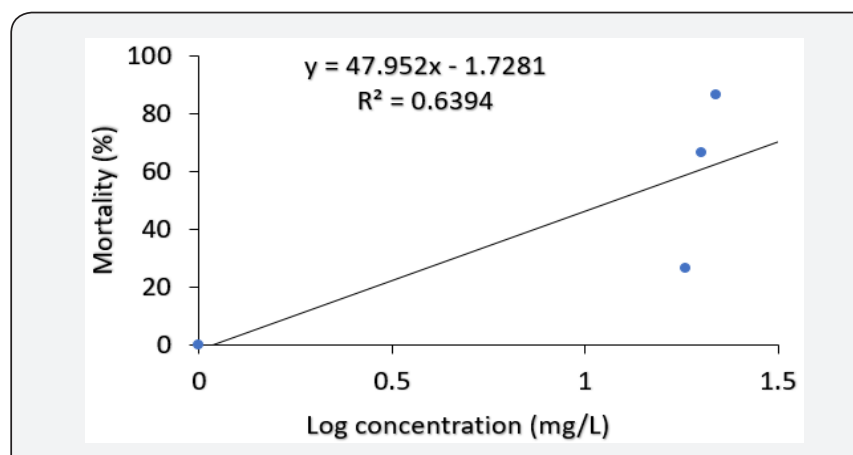

Figure 1: A plot of percent mortality against the log concentration of dichlorvos within 96 hours of exposure. 


\section{Discussion}

The present study is to demonstrate the toxic effects of dichlorvos in the juveniles of the freshwater fish Clarias gariepinus. In this study, the survival rate of $C$. gariepinus decreased as the concentration of dichlorvos increased. At 96hour exposure to dichlorvos, the mortality percent for control, 18, 20 and $22 \mathrm{mg} / \mathrm{L}$ test samples were $0,27,67$ and 87 respectively. This finding agrees with earlier reports by Asuquo et al. Oti, Adakole [11-13]. Toxicity of dichlorvos to organisms has however been shown to be dependent on concentrations, sex, developmental stages and exposure periods [14].

Behaviour provides a unique perspective linking the physiology and ecology of an organism and its environment and allows the organism to adjust to external and internal stimuli to best meet the challenge of surviving in a changing environment [15]. The results showed that dichlorvos affected the behavioural characteristics of $C$. gariepinus. The control specimens were not hyperactive and showed normal swimming patterns, skin colour, equilibrium status and fin movements throughout the exposure period. However, with increasing dichlorvos concentrations and exposure duration, hyperactivity, air gulping, erratic swimming and equilibrium instability increased. Besch [16] reported that there are contact (high excitability in a moment), exertion (fast swimming, leaping and attempts to jump out of the toxicant), equilibriuminstabilityand death phasescharacterisingbehavioural responses of fish to toxicants. Prolonged exposure to dichlorvos imposed tiredness and stress on the fish suggesting that there is insufficient intake of oxygen accompanied with detrimental effect on energy production, body building mechanism and ultimately nervous breakdown of fish. Heath, Kormakik \& Cameron, Kumar \& Krishna Moorthy [17-19] reported deleterious limitations in the use of energy synthesising macromolecules in fish subjected to environmental stress. The quality of water for dichlorvos did not show any significant change in the mean value of $\mathrm{pH}$, temperature and dissolved oxygen compared to the control. The values fall within the normal range of water quality for aquaculture [20]. In this research the 96 hours exposure has $17.21 \mathrm{mg} / \mathrm{L} \mathrm{LC}_{50}$ values with lower and upper confidence limits of 15.78 and 18.19 respectively. Ofojekwu et. al. [21] reported $\mathrm{LC}_{50}$ value of $15.85 \mathrm{~g} / \mathrm{L}$ for fingerlings of Tilapia zilli exposed to urea fertiliser. Toxicity of pesticides to organisms is affected by the strains of species, size, age, sex, temperature, water quality and formulation of the test chemicals [22]. Fishes are more susceptible to the environmental variations and respond more to pollutants than mammals. The fish liver has been shown as a model for studying the relationship between environmental factors with the hepatic structures and the functions [23]. Hepatosomatic Index (HSI) and Condition Factor (CF) gives an indication of the overall health condition of fish and have been widely used as stress indicator due to environmental pollutants [24]. In the present study, there was a significant reduction in HSI and CF on day 15 following exposure to 21 and $43 \mathrm{mg} / \mathrm{L}$ compared to day 1 respectively. Jordan et. al. [25] reported decreased CF in fish exposed to various toxicants.
The HSI values are generally elevated in vertebrates experiencing induction of hepatic microsomal P-450 for detoxification of the pollutants while decline in the HSI and CF may suggest a general detrimental effect of dichlorvos pesticide on the liver of fish [26].

\section{References}

1. Calamari D, Naeve H (1994) Towards management of the aquatic environment. CIFA Technical paper (FAO) Technical papers 25: 7-22.

2. Todd NE, Leuwen MV (2002) Effect of Cararyl insecticide on early life stages of zebra fish Danio rerio. Ecotoxicology Environmental Safety 53: 267-272.

3. Pancetti F, Olmos C, Dagnino-Subiabre A, Rozas C, Morales B (2007) Noncholinesterase effects induced by organophosphates pesticides and their relationship to cognitive processes: Implication for the action of acylpeptide hydrolase. J Toxicol Environ Health B Crit Rev 10(8): 623-630.

4. Suchismta D (2013) A review of dichlorvos toxicity to fish. Current World Environment 8(1): 143-149.

5. WHO (2005) International programme on chemical safety. WHO recommended classification of pesticides by Hazard and Guidelines to classification.

6. Baskaran P, Palanizhamy S, Visalakshi S, Balasubramanian MP (1989) Effects of mineral fertiliser on survival of the fish Oreochromis mossambicus. Environmental Ecology journal 7: 463-465.

7. Kalavanthy K, Sivakumar AA, Chandran R (2001) Toxic effect of the pesticide Dimethoate on the fish Sarotherodon mossambicus. Journal of Ecological Research and Bioconservative 2(1-2): 189-195.

8. Sambhu C (2004) African Catfish, Clarias gariepinus (Burchell, 1822): An ideal candidate for bio-waste management. Indian J Exp Biol 42(12): 1226-1229.

9. (1985) Standard method for examination of water and waste waters. In: Arnold E Greenberg (ed). (21 ${ }^{\text {th }}$ edn). New York. 1193p.

10. Finney DJ (1947) Probit analysis: a statistical treatment of the sigmoid response curve. Cambridge University Press p256.

11. Asuquo IE, Essien-Ibok MA and Abiabo NO (2016) The effects of some agricultural fertilizers on fingerlings of Heterobranchus bidorsalis. Journal of Aquaculture \& Marine Biology 4(2): 1-7.

12. Oti EE (2002) Acute toxicity of cassava mill effluent to the African Catfish fingerlings. Journal of Aquatic Sciences 17(1):31-35.

13. Adakole JA (2005) Acute toxicity of metal finishing company waste water to Clarias gariepinus fingerlings. Journal of Aquatic. Sciences 20(2): 69-73.

14. Pandey AK, Nagpure NS, Trivedi S (2011) Pronfenofos induced DNA damage in freshwater fish Channa punctatus using alkaline single cell gel electrophoresis. Mutat Res 726: 209-214.

15. Adewum AA, Olakje VF (2011) Catfish culture in Nigeria: progress, prospect and problems. Africa journal of Agriculture Research 6(6): 1281-1285.

16. Besch WK (1975) A biological monitoring system employing rheotaxis of fish. Proceedings of symposium on Biological Monitoring of water quality and waste water quality. Blacksbury USA p. 28-32.

17. Heath GA (1995) Water pollution and fish physiology. In: ( $2^{\text {nd }}$ edn). CRC Press, Florida p. 254.

18. Kormakik GA, Cameron JN (1981) Ammonia excretion in animals that breathe water: a review. Marine Biology 2: 11-23.

19. Kumar NJ, Krishnamoorthi KP (1983) Evaluation of toxicity of ammoniacal fertiliser effluents. Environmental pollution Service and Ecological Biology 30(1):77-86. 
20. Adeniji HA, Ovie SI (1989) A simple guide to water quality management in fish ponds. National Institute for Freshwater Fisheries Research 23.

21. Ofojekwu PC, Nwani CD, Chinedu C (2008) Acute toxicity of NPK (15:15:15) fertilisers of Tilapia zilli fingerlings. Nigeria journal of Fisheries 5(1):31-37.

22. QECD (1992) Guidelines for testing of chemicals, fish acute toxicity test. Organisation for economic cooperation and development Paris, France 203:1-9.

23. Ensibi C, Perez-Lopez M, Soler Rodriguez F, Miguez-Santiyan MP, Daly Yahya MN, et al. (2015) Effects of semi-static exposure to carburant in liver phase I and phase II enzymes of common carp (Cyprinus carpio). Journal of Environmental and Analytical Toxicology 5(3): 1-5.
24. Adams SM, Barton B, Mac Kinlay D (2002) Environmental stress and health in fish. Symposium proceedings in international congress on the biology of fish, American Fisheries society, University of British, Colombia, Vancouver, Canada.

25. Jordan MS, Reineeke SA, Reinecke AJ (2013) Biomaker responses and morphological effects in juvenile Tilapia Oreochromis mossambicus following sequential exposure to the organophosphate azinphosemthyl. Aquat Toxicol 15(144-145):133-140.

26. Adeyemi JA (2014) Oxidative stress and antioxidant enzymes activities in the African catfish Clarias gariepinus, experimentally challenged with Escericia coli and Vibrio fishcheri. Fish Physiology and Biochem 40: 347-354.

Your next submission with Juniper Publishers will reach you the below assets

- Quality Editorial service

- Swift Peer Review

- Reprints availability

- E-prints Service

- Manuscript Podcast for convenient understanding

- Global attainment for your research

- Manuscript accessibility in different formats

( Pdf, E-pub, Full Text, Audio)

- Unceasing customer service

Track the below URL for one-step submission

https://juniperpublishers.com/online-submission.php 